Komang Junia Adi Purnama, I Gusti Ngurah Japa, I Made Suarjana. (2020). Efektivitas Model Pembelajaran Two Stay Two Stray (TSTS) dalam Meningkatkan Hasil Belajar Matematika. Jurnal Penelitian dan Pengembangan Pendidikan. Vol. 4 (3) pp. 343-350.

\title{
Efektivitas Model Pembelajaran Two Stay Two Stray (TSTS) dalam Meningkatkan Hasil Belajar Matematika
}

\author{
Komang Junia Adi Purnama1*, I Gusti Ngurah Japa², I Made Suarjana3 \\ 123 Program Studi Pendidikan Guru Sekolah Dasar Universitas Pendidikan Ganesha, Singaraja, Indonesia
}

\begin{abstract}
Abstrak
Rendahnya hasil belajar matematika siswa dan pembelajaran masih berpusat pada guru (teacher centered) menjadi masalah utama penelitian ini. Penelitian ini bertujuan untuk mengetahui efektivitas Model pembelajaran Two Stay Two Stray terhadap hasil belajar Matematika. Penelitian ini menggunakan metode pencatatan dokumen yang berkaitan dengan model pembelajaran Two Stay Two Stray terhadap hasil belajar Matematika di sekolah dasar yang dianalisis menggunakan pendekatan deskriptif kuantitatif yakni meta analisis dengan kegiatan yang dilaksanakan sebagai berikut; (1) menentukan dan mempelajari topik penelitian yang akan dirangkum, (2) mencari dan mengumpulkan sejumlah topik yang telah ditentukan dan menyeleksinya, (3) melakukan perhitungan effect size dengan mengidentifikasi mean dan standar deviasi dari perhitungan uji $t$ yang telah dilakukan, dan (4) menarik kesimpulan dan menginterprestasikan hasil penelitian meta analisis. Hasil analisis effect size memaparkan bahwa dari ke 7 penelitian yang relevan hanya terdapat 5 penelitian yang dapat diukur efektivitasnya dikarenakan data yang disajikan lengkap dengan perolehan perhitungan effect size model pembelajaran Two Stay Two Stray efektif terhadap hasil belajar Matematika siswa dengan hasil belajar Matematika berada pada kategori sangat tinggi. Sehingga, dapat disimpulkan bahwa model pembelajaran Two Stay Two Stray efektif dalam meningkatkan hasil belajar matematika siswa.
\end{abstract}

Kata Kunci:

Two Stay Two Stray, Hasil Belajar, Efektivitas

\begin{abstract}
The low student learning outcomes in mathematics and teacher centered learning are the main problems of this study. This research aims to determine the effectiveness of Two Stay Two Stray learning model on mathematics learning outcomes. This research uses the method of recording documents related to the Two Stay Two Stray learning model on mathematics learning outcomes in elementary schools which are analyzed using a quantitative descriptive approach namely meta-analysis. The activities are; (1) determine and study the research topic to be summarized, (2) find and collect some topics that have been determined and selected, (3) calculate the effect size by identifying the mean and standard deviation of the t-test calculations that have been done, and (4) stated conclusions and interpret the results of meta-analysis research. The result of the analysis of the effect size explained that from 7 relevant researches, there were only 5 researches that could be measured for the effectiveness because the data presented were complete with the calculation of the effect size of the Two Stay Two Stray learning model effective on students Mathematics learning outcomes, with the mathematics learning outcomes in the very high category. From the results of the t test, it can be concluded that the Two Stay Two Stray learning model can improve student mathematics learning outcomes.
\end{abstract}

Keywords:

Two Stay Two Stray, Learning Outcomes, Effectiveness

\footnotetext{
* Corresponding author. 


\section{PENDAHULUAN}

Pendidikan merupakan aspek yang paling penting yang tidak bisa lepas dari kehidupan manusia. Pendidikan juga merupakan salah satu sarana untuk mengembangkan potensi diri dan keterampilan siswa melalui proses pembelajaran sebagai bekal dirinya menjalani hidup bermasyarakat, berbangsa, dan bernegara. Menurut Saidah (2016), suatu pendidikan ialah adanya proses pemberian pengetahuan, pelatihan, pengajaran, maupun di dalam pengembangan suatu keterampilan. Pendidikan dipandang bukan semata-mata sebagai sarana untuk menyiapkan individu bagi kehidupannya di masa depan tetapi juga untuk kehidupan anak sekarang yang sedang mengalami perkembangan menuju ke tingkat kedewasaan. Sedangkan Saputra (2017), menyatakan Pendidikan sebgai suatu proes yang diperoleh oleh individu dimana mereka mampu memahami, mengerti, dan mengkritisi suatu hal di dalam berfikir khususnya dalm pembelajaran mata pelajaran matematika. Hal tersebut sejalan dengan pendapat Ukur (2020) "Pendidikan adalah usaha sadar dan terencana untuk mewujudkan suasana belajar dan proses pembelajaran agar peserta didik secara aktif dapat mengembangkan potensi dirinya serta keterampilan yang diperlukan dirinya dan masyarakat". Dari pernyataan-pernyataan diatas dapat di tarik kesimpulan bahwa Pendidikan adalah usaha sadar dan terencana dalam mengembangkan keterampilan dan menambah pengetahuan untuk mengembangkan potensi dirinya sendiri. Sekolah dasar adalah awal bagi seseorang untuk memulai pendidikannya sebelum mengikuti jenjang selanjutnya.

Mata pelajaran matematika pada jenjang Sekolah Dasar (SD) memiliki peran penting dalam kehidupan. Menurut Solihah (2016), Matematika ialah suatu pelajaran yang sangat diperlukan dalam berbagai bidang di dunia. Mata pelajaran Matematika perlu diberikan kepada semua peserta didik mulai dari SD untuk membekali peserta didik dengan kemampuan berpikir logis, analitis, sistematis, kritis, dan kreatif, serta kemampuan bekerjasama (Soviawati, 2011). Dengan matematika, siswa dilatih untuk berpikir logis, sistematis, dan kritis. Pembelajaran matematika di sekolah agar mampu mengembangkan potensi yang dimiliki siswa, sehingga mereka mampu memahami pembelajaran matematika dengan benar (Danic, Japa, \& Diputra, 2019). Tujuan pembelajaran matematika bukan hanya agar siswa mampu menyelesaikan soal-soal rutin matematika (soal ulangan harian, ujian semester, ujian nasional, maupun ujian masuk ke jenjang yang lebih tinggi). Namun tujuan pembelajaran matematika harus diarahkan kepada tujuan yang lebih komprehensif, sesuai dengan tuntutan kurikulum yaitu: (1) Memahami konsep matematika, menjelaskan keterkaitan antar konsep dan mengaplikasikan konsep atau algoritma, secara luwes, akurat, efisien, dan tepat, dalam pemecahan masalah; (2) Menggunakan penalaran pada pola dan sifat; (3) Memecahkan masalah yang meliputi kemampuan memahamimasalah, merancang model matematika, menyelesaikan model dan menafsirkan solusi yang diperoleh; (4) Mengkomunikasikan gagasan; (5) Memiliki sikap menghargai kegunaan matematika dalam kehidupan, yaitu memiliki rasaingin tahu, perhatian, dan minat dalam mempelajari matematika, serta sikap ulet dan percaya diri dalam pemecahan masalah (Kamarullah, 2017). Dengan demikian, salah satu tujuan dari pembelajaran matematika diberikan di sekolah dasar yakni agar siswa mampu memahami konsep matematika sehingga mencapai hasil belajar matematika yang tinggi.

Hasil belajar matematika mencerminkan siswa tersebut mampu memahami atapun kurang dalam pelajaran matematika. Menurut Sanjaya dalam (Aristia, 2018), "hasil belajar adalah kemampuan individu yang diperoleh setelah proses pembelajaran berlangsung yang dapat memberikan perubahan tingkah laku, pengetahuan, pemahaman dan keterampilan peserta didik sehingga menjadi yang lebih baik dari sebelumnya". Hasil belajar matematika juga dapat diartikan yaitu hasil akhir yang dimiliki atau diperoleh siswa setelah ia mengalami proses belajar matematika yang ditandai dengan skala nilai berupa huruf atau simbol atau angka, dan hal ini biasa dijadikan tolak ukur berhasil atau tidaknya siswa tersebut dalam pembelajaran matematika (Firmansyah, 2015). Hasil beajar mateatika siswa sangat ditentukan pengaruhnya oleh pendidik atau guru.

Guru merupakan salah satu komponen dalam proses pembelajaran yang ikut berperan dalam usaha pembentukan sumber daya manusia yang berkualitas Menurut Roqib \& Nurfaudi (2020) bahwa guru adalah sosok yang memiliki rasa tanggung jawab sebagai seorang pendidik dalam menjalankan tugas dan fungsinya sebagai seorang guru secara profesional yang pantas menjadi figur atau teladan bagi peserta didiknya. Sedangkan menurut Djamarah (Dasem, Laka, \& Niwele, 2018:128) bahwa "Guru adalah figur manusia sumber yang menempati posisi dan memegang peran penting dalam pendidikan". Peran guru lebih diarahkan pada bagaimana guru merancang atau mengaransemen berbagai sumber dan fasilitas yang tersedia untuk digunakan atau dimanfaatkan siswa dalam mempelajari sesuatu. Menurut Sunila, Dantes, \& Candiasa (2013), di dalam kegiatan pembelajaran peran guru sebagai fasilitator hendaknya memfasilitasi siswa dalam kegiatan pembelajaran, sedangkan guru sebagai motivator dimaksudkan guru memotivator siswa agar implikasi pembelajaran mengarahkan pada pembelajaran efektif dan efisien. 
Namun dalam pelaksanaannya tujuan pembelajaran maupun komponen yang ada tidak selalu berjalan sesuai rencana, terdapat berbagai permasalahan, untuk itu guru berusaha agar dapat memecahkan permasalahan dalam proses pembelajarannya. Hal tersebut sejalan dengan skor PISA di Indonesia untuk matematika yang menjadi pekerjaan rumah besar, rerata skor PISA negara anggota untuk matematika 489. Mengikuti tes PISA sejak tahun 2000, pada tahun 2018 skor PISA Indonesia untuk matematika berkisar di angka 379. Sebagai pembanding, China dan Singapura menempati peringkat tinggi untuk matematika dengan skor 591 dan 569. Sependapat dengan hal tersebut Hadi (2017) juga berpendapat bahwa "Data menunjukkan bahwa nilai rerata dalam ujian akhir nasional selalu di bawah 5, senada dengan kompetesi interasioal seperti IMO (International Mathematics Olympiad) siswa Indonesia menjukkan kinerja yang rendah".

Hal ini diperkuat melalui hasil observasi dan kajian dokumen tanggal 30 Oktober 2019 yang telah dilakukan peneliti pada salah satu SD. Berdasarkan hasil observasi, guru masih menggunakan model pembelajaran konvensional dan skor hasil belajar ulangan tengah semester mata pelajaran Matematika yang belum optimal. Permasalahan yang terjadi tersebut juga didukung pada saat melakukan waawancara di salah satu SD, adapun penyebab dari skor hasil belajar matematika siswa yang rendah yaitu 1) pembelajaran masih berpusat pada guru (teacher centered); 2) Guru hanya mentransfer pengetahuan kepada siswa sehingga siswa hanya menerima tanpa menemukan langsung pengetahuannya; 3) Pembelajaran di dalam kelas tersebut hanya membuat anak untuk menghafal materi yang disampaikan oleh guru; 4)Siswa diajak hanya menghafalkan rumus-rumus apa yang telah dijelaskan oleh guru dan kondisi ini membuat siswa cenderung pasif; dan 5) kurangnya pemanfaatan sarana dan prasarana penunjang kegiatan pembelajaran seperti alat peraga tidak mencukupi. Saat proses pembelajaran guru jarang memperlihatkan fenomena nyata atau media yang berhubungan dengan materi yang dibahas. Fakta yang ditemukan dilapangan, guru masih mengajar melalui model konvensional. Proses pembelajaran matematika belum sesuai dengan harapan dari tercapainya tujuan pembelajaran matematika. Guru masih menerapkan model pembelajaran konvensional yang saat ini sering digunakan di sekolah dasar adalah metode ceramah. Metode cermah merupakan cara mengajar yang paling tradisional yang telah lam dijalankan dalam sejarah pendidikan, oleh karena itu metode ini boleh dikatakan sebagai pengajaran tradisional karena sejak dulu metode ini digunakan sebagai alat komunikasi guru dalam menyampaikan pelajaran (Hamdani, Indriani, \& Sunardjo, 2019).

Untuk dapat menciptakan situasi pembelajaran yang menyenangkan hendaknya guru dalam menyajikan materi pembelajaran memberikan kesempatan kepada siswa untuk menemukan sendiri, mengadakan penyelidikan melalui percobaan, mencoba menganalisis serta mendiskusikan dengan anggota kelompoknya. Berdasarkan permasalahan-permasalahan yang ditemukan dari wawancara, pengamatan dan juga studi dokumen yang dilakukan di SD, maka diperlukan suatu pembelajaran untuk mengoptimalkan hasil belajar matematika. Model pembelajaran tersebut adalah Model Pembelajaran Two Stay Two Stray (TSTS). Model pembelajaran Two Stay Two Stray adalah tipe pembelajaran berkelompok, dengan harapan siswa belajar bekerja sama dan saling membantu untuk memecahkan masalah. Berkelompok dapat melatih siswa untuk fokus pada proses belajar karena aktivitas siswa lebih diutamakan. Siswa dapat bertukar informasi kepada siswa yang lain untuk menyelesaikan masalah. Penggunaan model pembelajaran Two Stay Two Stray, akan meningkatkan motivasi siswa dalam belajar sebab siswa mempunyai tanggung jawab yang besar untuk dirinya atau kelompoknya (Setyowati, Relmasira, \& Hardini, 2019) . Model pembelajaran Two Stay Two Stray menurut Chotimah (2016) menyatakan bahwa "model pembelajaran kooperatif yang memberi kesempatan kepada kelompok untuk membagikan hasil dan informasi dengan kelompok lain". Sedangkan Shoimin, (2014), memaparkan bahwa model pembelajaran Two Stay Two Stray adalah dua orang siswa tinggal di kelompok dan dua orang siswa bertamu ke kelompok lain. Dari penjelasan tersebut penerapan model Two Stay Two Stray akan membantu guru untuk mengarahkan siswanya agar selalu memperhatikan pada saat penyampaian materi.

Model Pembelajaran Two Stay Two Stray (TSTS) memiliki tahapan-tahapan untuk bisa di terapkan dalam merancang proses pembelajaran yang akan diaplikasikan oleh guru sehingga pembelajaran men jadi inovatif dan menyenangkan yakni (Shoimin, 2014): 1) persiapan, 2) presentasi guru, 3) kegiatan kelompok, 4) formalisasi; 5) evaluasi kelompok dan penghargaan. Model TSTS memiliki keunggulan yakni siswa akan terlibat secara aktif di dalam proses pembelajaran, di dalam kelompok semua anggota kelompok tersebut diharuskan agar melaporkan hasil yang diperolehnya sehingga dapat memberikan efek peningkatan hasil belajar dan daya ingat (Manik \& Gafur, 2016). Adanya pembelajaran kelompok kecil dalam pembelajaran TSTS diharapkan peserta didik dapat saling bekerja sama dalam menyelesaikan suatu permasalahan-permasalahan dalam hal penemuan pemahaman konsep (Wuryanto, 2014). Model pembelajaran tipe Two Stay Two Stray (TSTS) adalah model pembelajaran kooperatif dengan sintaks: kerja kelompok, dua siswa bertamu ke kelompok lain dan siswa lainnya tetap di 
kelompoknya untuk memerima dua orang siswa dari kelompok lain, kerja kelompok kembali ke kolompok asal, kerja kelompok dan laporan kelompok (Amin, Charli, \& Fita, 2018).

Adapun untuk menunjang penelitian yang dilakukan ada beberapa penelitian tentang model pembelajaran Two Stay Two Stray, yang pertama penelitian yang dilakukan Kadek \& Arthaningsih (2018) yang menyatakan bahwa model pembelajaran Two Stay Two Stray berpengaruh signifikan terhadap hasil belajar matematika pada siswa kelas V SD. Kedua, penelitian yang dilakukan Yurniwati \& Handayani (2019) tentang model pembelajaran Two Stay Two Stray memperoleh hasil analisis yaitu terdapat perbedaan yang signifikan antara hasil belajar matematika yang menerapkan model pembelajaran Two Stay Two Stray dengan hasil pembelajaran yang menerapkan model pembelajaran konvensional, dengan nilai signifikansi 0,000>0,005. Ketiga, penelitian yang dilakukan Febriyanti, Jampel, \& Syahruddin (2014), tentang model Two Stay Two Stray dengan hasil penelitian yang menunjukkan bahwa penggunaan model pembelajaran Two Stay Two Stray berpengaruh terhadap peningkatan hasil belajar matematika siswa kelas V SD dengan $t_{\text {hitung }}=5,813>t_{\text {tabel }}=2,021$.

Bedasarkan paparan di atas perlu dikaji lebih jauh mengenai pengaruh model pembelajaran Two Stay Two Stray yang dari hasil penelitian dapat meningkatkan hasil belajar matematika, maka penelitian ini berjudul "Efektivitas Model Pembelajaran Two Stay Two Stray (TSTS) Terhadap Hasil Belajar Matematika Siswa SD"

\section{METODE PENELITIAN}

Jenis pendekatan penelitian ini menggunakan pendekatan penelitian meta analisis melalui kegiatan melakukan pengumpulan data dengan menelusuri google scholar atau google cendikia. Meta analisis pada hakekatnya merupakan sintesis sebuah topik yang diambil melalui beberapa laporan penelitian (Ansor, 2017). Di alam melakukan penelitian meta analisis terdapat langkah-langkah yang dapat dilakukan diantaranya; (1) menentukan dan mempelajari topik penelitian yang akan dirangkum, (2) mencari dan mengumpulkan sejumlah topik yang telah ditentukan dan menyeleksinya, (3) melakukanperhitungan effect size, dan (4) menarik kesimpulan dan menginterprestasikan hasil penelitian meta analisis (Waluyohadi, 2018). Adapun proses meta analisis yang dilakukan dalam penelitian ini terdapat dalam bagan berikut:

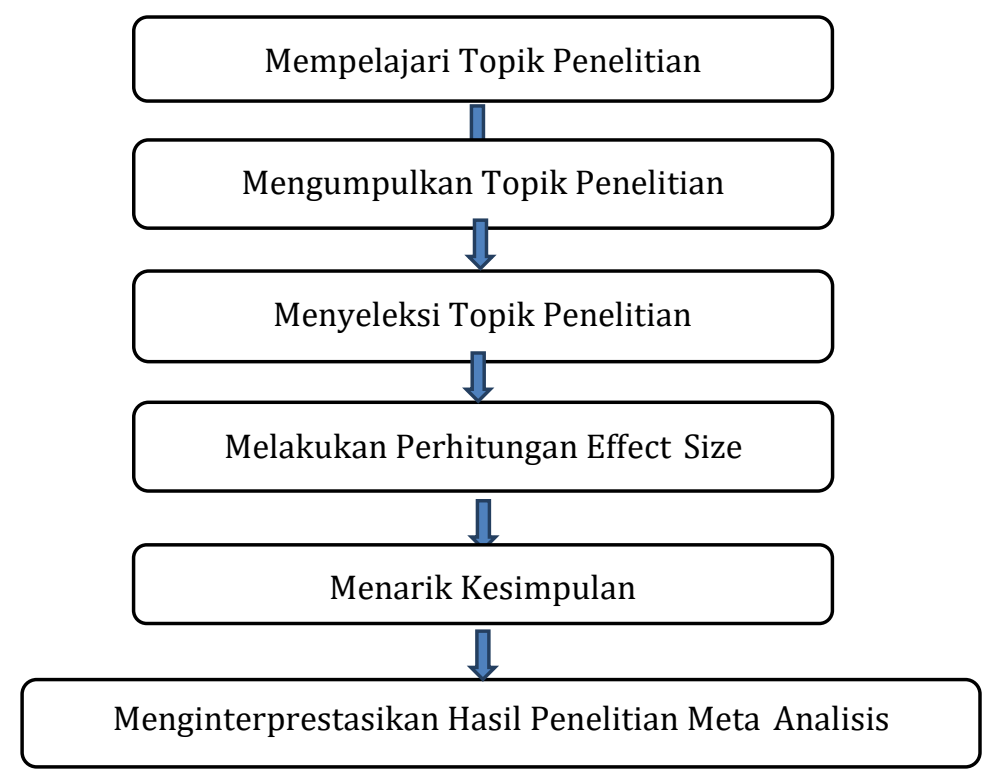

Gambar 1. Proses Meta Analisis

Sampel dalam penelitian ini adalah artikel yang berkaitan dengan model pembelajaran Two Stay Two Stray Terhadap hasil belajar matematika siswa sekolah dasar yang telah terpublikasi secara nasional yang tercatat lima tahun terakhir sejak 2015 sampai dengan tahun 2020, artikel-artikel yang telah terkumpul telah memiliki kesamaan sebagai berikut: (1) artikel dibuat oleh mahasiswa prodi pendidikan sekolah, guru-guru di sekolah dasar, maupun peneliti dibidang pendidikan sekolah dasar (2) menggunakan metode penelitian eksperimen yang telah dilaksanakan di sekolah dasar, (3) artikel 
merupakan penelitian kuantitatif dan memenuhi data effect size, dan (4) cakupan sampelpenelitian dilakukan di kawasan Indonesia.

Teknik pengumpulan data dalam penelitian ini adalah dengan metode dokumentasi Arikunto (2010:201) "Dokumentasi barang-barang tertulis" dimana dalam penelitian ini mencatat hasil belajar matematika siswa dengan melaukan pencatatan dokumen pada kajian-kajian penelitian yang relevan.

Teknik dasar dari penelitian meta analisis adalah effect size. Diani, Yubrti, \& Syafitri (2016), mengungkapkan bahwa Effect size menunjukkan sejauh mana suatu variabel dapat mempengaruhi variabel lain dalam suatu penelitian atau menunjukkan seberapa efektif suatu variabel mempengaruhi variabel lainnya. Melakukan perhitungan effect size melalui data-data penelitian yang terdapat dalam artikel yang relevan dengan cara mengidentifikasi rerata dan standar deviasi data kelompok eksperimen dan kelompok kontrol yang digunakan untuk memperoleh effect size.

\section{ANALISIS DAN PEMBAHASAN}

Model pembelajaran Two Stay Two Stray terhadap hasil belajar Matematika dinyatakan efektif hal ini terbukti dari ke lima artikel yang ditemukan diperoleh efektivitas model pembelajaran Two Stay Two Stray terhadap hasil belajar Matematika Siswa Sekolah Dasar pada kategori tinggi. Pengaruh metode pembelajaran Two Stay Two Stray efektif meningkatkan hasil belajar Matematika.

Menurut Arianti, Akib, \& Saleh (2017), model pembelajaran kooperatif tipe Two Stay Two Stray (TSTS) yaitu memberi kesempatan kepada kelompok untuk mengembangkan hasil informasi dengan kelompok lain dengan cara dua anggota kelompok yang tinggal dan dua anggota kelompok sebagai tamu. Masing-masing kelompok bekerjasama sehingga dalam proses pemecahan masalah dapat terlaksana dengan baik guna mencapai prestasi yang diinginkan. Selanjutnya, untuk dapat menguji informasi yang didapatkan oleh setiap kelompok pada akhir pembelajaran dibuat rangkuman dimana setiap siswa akan mempresentasikan hasil pembelajaran yang didapatkan, dan kelompok yang memperoleh informasi sesuai dengan materi akan diberikan penghargaan, dengan kegiatan ini tentunya dapat meningkatkan hasil belajar siswa.

Hasil Penelitian ini sejalan dengan pendapat Rediarta, Sudarma, \& Murda (2014) menyebutkan bahwa TSTS memberikan kesempatan kepada siswa untuk belajar lebih bermakna sehingga memudahkan siswa menyerap informasi yang diberikan. Selain itu, model pembelajaran TSTS yang dapat diberikan pada semua tingkatan atau mata pelajaran dan melibatkan siswa secara aktif dalam proses diskusi yang dilakukan mendorong minat siswa untuk belajar.

Tabel 1. Data Pengelompokan Effect Size Secara Keseluruhan

\begin{tabular}{|c|c|c|c|c|}
\hline No & $\begin{array}{l}\text { Penelitian yang } \\
\text { dilakukan oleh }\end{array}$ & Judul & Effect Size & Kategori \\
\hline 1 & $\begin{array}{c}\text { Kadek \& } \\
\text { Arthaningsih (2018) }\end{array}$ & $\begin{array}{l}\text { Pengaruh Model Pembelajaran } \\
\text { Kooperatif Tipe Two Stay Two Stray } \\
\text { melalui Lesson Study terhadap Hasil } \\
\text { Belajar Matematika }\end{array}$ & 1.48 & $\begin{array}{c}1.48>1.45 \\
\text { (sangat tinggi) }\end{array}$ \\
\hline 2 & $\begin{array}{l}\text { Handayani, Slameto, } \\
\text { \& Radia (2018) }\end{array}$ & $\begin{array}{l}\text { Efektivitas Model Pembelajaran Two } \\
\text { Stay Two Stray (TSTS) Ditinjau dari } \\
\text { Hasil Belajar Siswa Kelas V SD pada } \\
\text { Mata Pelajaran Matematika }\end{array}$ & 3.01 & $\begin{array}{c}3.01>1.45 \\
\text { (sangat tinggi) }\end{array}$ \\
\hline 3 & $\begin{array}{l}\text { Dawani, Margiyati, } \\
\text { \& Sabri (2018) }\end{array}$ & $\begin{array}{l}\text { Pengaruh Penggunaan Model } \\
\text { Kooperatif Tipe Two Stay Two Stray } \\
\text { Terhadap Hasil Belajar Matematika } \\
\text { SD }\end{array}$ & 2.96 & $\begin{array}{c}2.96>1.45 \\
\text { (sangat tinggi) }\end{array}$ \\
\hline 4 & $\begin{array}{l}\text { Febriyanti et al., } \\
\qquad(2014)\end{array}$ & $\begin{array}{l}\text { Pengaruh Metode Pembelajaran Two } \\
\text { Stay Two Stray Berbantuan Media } \\
\text { Konkret Terhadap Hasil Belajar } \\
\text { Matematika Siswa Kelas V }\end{array}$ & 3.18 & $\begin{array}{c}3.18>1.45 \\
\text { (sangat tinggi) }\end{array}$ \\
\hline 5 & $\begin{array}{l}\text { Astesya, Wasitohadi, } \\
\text { \& Rahayu (2018) }\end{array}$ & $\begin{array}{l}\text { Efektivitas Penggunaan Model } \\
\text { Pembelajaran Kooperatif Tipe TSTS } \\
\text { Dengan TPS Terhadap Hasil Belajar } \\
\text { Matematika Siswa Kelas V SD }\end{array}$ & 1.73 & $\begin{array}{c}1.73>1.45 \\
\text { (sangat tinggi) }\end{array}$ \\
\hline
\end{tabular}


Hasil analisis data dengan effect size artikel juga ditemukan bahwa dari ke lima artikel tersebut diperoleh efektivitas model pembelajaran Two Stray Two Stray paling tinggi terletak pada penelitian Pengaruh Metode Pembelajaran Two Stay Two Stray Berbantuan Media Konkret Terhadap Hasil Belajar Matematika Siswa Kelas V oleh Febriyanti et al., (2014), dengan effect size yaitu 3.18. Sedangkan penelitian yang dilakukan oleh Kadek \& Arthaningsih (2018)yang berjudul Pengaruh Model Pembelajaran Kooperatif Tipe Two Stay Two Stray melalui Lesson Study terhadap Hasil Belajar Matematika paling kecil dengan effect size yaitu 1.48 .

Penelitian yang dilakukan di dalam penelitian ini terdapat beberapa perbedaan dengan penelitian yang relevan. Pada penelitian oleh Kadek \& Arthaningsih (2018), terdapat perbedaan penelitian dengan menggunakan tambahan Lesson Study yang memperoleh hasil belajar yang tinggi. pada penelitian Pengaruh Metode Pembelajaran Two Stay Two Stray Berbantuan Media Konkret Terhadap Hasil Belajar Matematika Siswa Kelas V oleh Febriyanti et al., (2014). Model pembelajaran Two Stay Two Stray yang dipadukan dengan media benda kongkret dapat meningkatkan hasil belajar Matematika siswa karena menurut pendapat Wirnawati, Tampubolon, \& Asran, n.d.), bahwa media konkret dapat memudahkan siswa memahami materi pembelajaran pada umumnya bersifat abstrak, dengan menggunakan media benda konkret dapat memberikan pengalaman langsung kepada siswa untuk memahami pembelajaran.

Berdasarkan beberapa kajian penelitian, pada penggunaan model pembelajaran Two Stay Two Stray dapat diketahui bahwa hasil belajar matematika siswa mengalami peningkatan yang signifikan dengan yang dibelajarkan menggunakan pembelajaran konvensional.Selain itu, efektivitas penggunaan model pembelajaran Two Stay Two Stray dapat terlihat dari hasil penelitian yang telah dikaji.Hasil tersebut menunjukkan penelitian yang telah dikaji pada model pembelajaran Two Stay Two Stray dapat diterapkan dalam penelitian dan dapat mendukung penelitian.

\section{KESIMPULAN}

Berdasarkan temuan dan hasil penelitian yang telah dilakukan, maka dapat disimpulkan yaitu secara keseluruhan dari 7 hasil penelitian yang relevan terdapat 5 artikel yang data hasil penelitiannya lengkap dan dapat dihitung menggunakan meta-analisis, model pembelajaran Two Stay Two Stray mampu meningkatkan hasil belajar matematika siswa pada kelompok eksperimen yang mendapat hasil lebih besar dari kelompok kontrol. Hal tersebut menunjukkan bahwa model pembelajaran Two Stay Two Stray memberikan pengaruh yang lebih efektif dan model pembelajaran Two Stay Two Stray layak digunakan dalam pembelajaran matematika. Adanya perbedaan yang signifikan menunjukkan bahwa penggunaan model pembelajaran TSTS berpengaruh positif terhadap hasil belajar siswa dalam pembelajaran Matematika dibandingkan dengan pengajaran konvensional. Selain itu, model Two Stay Two Stray dapat mendorong kepercayaan dan partisipasi siswa. Adapun saran dari penelitian ini ditujukan kepada berbagai pihak, yaitu diharapakan Bagi Guru, dapat menambah wawasan dan pengetahuan bagi guru terdapat model pembelajaran yang bisa diterapkan untuk pelajaran Matematika. Bagi Kepala Sekolah, dapat menjadi masukan yang positif dalam meningkatkan kualitas pembelajaran dengan menciptakan pembelajaran yang kreatif dan inovatif di sekolah sehingga dapat dijadikan sebagai bahan kajian evaluasi untuk meningkatkan kualitas pendidikan sekolah. Bagi Peneliti Lain, dijadikan bahan referensi oleh peneliti lain dalam memberikan gambaran seberapa efektifnya menggunakan model Two Stay Two Stray terhadap hasil belajar Matematika siswa SD dengan analisis data yang lengkap ditampilkan pada penelitian.

\section{DAFTAR PUSTAKA}

Amin, A., Charli, L., \& Fita, W. N. (2018). Pengaruh Model Pembelajaran Kooperatif Tipe Jigsaw dan Konvesional terhadap Hasil Belajar Fisika. Science and Physics Education Journal (SPEJ), 2(1), 1117. https://doi.org/10.31539/spej.v2i1.424

Ansor, S. (2017). Studi Meta Analisis Strategi dan Pemanfaatan Jurnal Elektronik (e - journals) untuk Mahasiswa Lulusan Universitas Negeri Malang dalam Upaya Publikasi Ilmiah Bereputasi Internasional. E-Journal Universitas Airlangga, 3(5), 63-73.

Arianti, R., Akib, H., \& Saleh, S. (2017). Penggunaan Model Pembelajaran Kooperatif Tipe Two Stay Two Stray ( TSTS ) pada Jurusan Administrasi Perkantoran di SMK Negeri 1 Pinrang The Use of Cooperative Learning Type Two Stay Two Stray ( TSTS ) in Office Administration Program at State Vocational S. Jurnal Office, 3(2). 
Aristia, R. (2018). Implementasi Model Pembelajaran Problem Based Learning pada Pembelajaran IPA untuk Meningkatkan Hasil Belajar Siswa MI Walisongo Gempol. Universitas Muhammadiyah Sidoarjo. https://doi.org/10.1017/CB09781107415324.004

Astesya, M., Wasitohadi, \& Rahayu, T. S. (2018). Efektivitas Penggunaan Model Pembelajaran Kooperatif Tipe Tsts (Two Stay Two Stray) Dengan Tps ( Think Pair Share) Terhadap Hasil Belajar Matematika Siswa Kelas V SD. Didaktika Dwija Indria, 6(2), 8-19.

Chotimah, H. (2016). Peningkatan Keterampilan Diskusi Siswa Kelas X Sman 1 Pleret, Bantul Melalui Model Pembelajaran. Jurnal Ilmiah Edukasi \& Sosial, 8(1), 29-40.

Danic, I., Japa, I. G. N., \& Diputra, K. S. (2019). Penguatan Kemampuan Pemecahan Masalah Matematika Siswa Melalui Pembelajaran Matematika Realistik Berbasis Open-Ended. Jurnal Ilmiah Pendidikan Citra Bakti, 6, 9-22. https://doi.org/10.1017/CB09781107415324.004

Dasem, A. A., Laka, B. M., \& Niwele, A. (2018). Peranan Guru Dalam Proses Pembelajaran Bahasa Indonesia Di SD Inpres Komboi Kabupaten Biak Numfor. WACANA AKADEMIKA: Majalah Ilmiah Kependidikan, 2(2), 126-136.

Dawani, Margiyati, \& Sabri. (2018). Pengaruh Penggunaan Model Kooperatif Tipe Two Stay Two Stray Terhadap Hasil Belajar Matematika SD. . 7 (9). Jurnal Pendidikan Dan Pembelajaran Khatulistiwa, 9.

Diani, R., Yubrti, \& Syafitri, S. (2016). Uji Effect Size Model Pembelajaran Scramble Dengan Media Video Terhadap Hasil Belajar Fisika Peserta Didik Kelas X Man 1 Pesisir Barat. Jurnal Ilmiah Pendidikan Fisika Al-BiRuNi, 05(2), 265-275. https://doi.org/10.24042/jpifalbiruni.v5i2.126

Febriyanti, E. A. W., Jampel, I. N., \& Syahruddin, H. (2014). Pengaruh Metode Pembelajaran Two Stay Two Stray Berbantuan Media Konkret Terhadap Hasil Belajar Siswa Kelas V. Jurnal Mimbar PGSD Universitas Pendidikan Ganesha, 1(1).

Firmansyah, D. (2015). Pengaruh Strategi Pembelajaran Dan Minat Belajar Terhadap Hasil Belajar Matematika. Jurnal Pendidikan Unsika, 3, 34-44.

Hadi, S. (2017). Pendidikan Matematika Realistik: Teori, Pengembangan, dan Implementasinya. Jakarta: Rajawali Pers.

Hamdani, R., Indriani, D. E., \& Sunardjo. (2019). Pengaruh Penggunaan Metode Diskusi Kelompok dan Metode Ceramah Terhadap Hasil Belajar Pendidikan Kewarganegaraan Siswa Kelas VII MTs Miftahul Mubtadiin. Jurnal Ilmu Pendidikan PKn Dan Sosial Budaya, 9924, 185-194.

Handayani, N., Slameto, \& Radia, E. H. (2018). Efektivitas Model Pembelajaran Two Stay Two Stray ( TSTS ) Ditinjau dari Hasil Belajar Siswa Kelas V SD pada Mata Pelajaran Matematika. International Journal of Elementary Education, 2(1), 15-21.

Kadek, N., \& Arthaningsih, J. (2018). Pengaruh Model Pembelajaran Kooperatif Tipe Two Stay Two Stray melalui Lesson Study terhadap Hasil Belajar Matematika. Journal of Education Technology, 2(4), 128-136.

Kamarullah. (2017). Pendidikan Matematika Di Sekolah Kita. Al Khawarizmi: Jurnal Pendidikan Dan Pembelajaran Matematika, 1(1), 21-32.

Manik, K., \& Gafur, A. (2016). Penerapan Model Two Stay Two Stray Berbantuan Multimedia Untuk Meningkatkan Aktivitas Dan Hasil Belajar Ips. Harmoni Sosial: Jurnal Pendidikan IPS, 3(1), 39-49. https://doi.org/10.21831/hsjpi.v3i1.9693 
Rediarta, I. W., Sudarma, I. K., \& Murda, I. N. (2014). Pengaruh Model Kooperatif Two Stay Two Stray Terhadap Hasil Belajar IPA. Jurnal M, 2(1).

Roqib, \& Nurfaudi. (2020). Kepribadian Guru Upaya Mengembangkan Kepribadian Guru Yang Sehat di Masa Depan. Purwokerto: CV. Cinta Buku.

Saidah. (2016). Pengantar Pendidikan. Jakarta: PT RajaGrafindo Persada.

Saputra, I. M. D. (2017). Pendidikan Anak Usia Dini dalam Tembang “Cening Ayu." Pratama Widya: Jurnal Pendidikan Anak Usia Dini, 2(2), 51-57.

Setyowati, Y. E., Relmasira, S. C., \& Hardini, A. T. A. (2019). Peningkatan Keaktifan Dan Hasil Belajar Pada Pembelajaran Muatan Ipa Dengan Menggunakan Model Two Stay Two Stray Sekolah Dasar. Jurnal Elementaria Edukasia, 2(1), 54-63.

Shoimin, A. (2014). 68 Model Pembelajaran Inovatif Dalam Kurikulum 2013. Yogyakarta: Ar-Ruzz Media.

Solihah, A. (2016). Pengaruh Model Pembelajaran Teams Games Tournament (Tgt) Terhadap Hasil Belajar Matematika. Jurnal Sap, 1(1), 45-53.

Soviawati, E. (2011). Pendekatan Matematika Realistik (Pmr) Untuk Meningkatkan Kemampuan Berfikir Siswa Di Tingkat Sekolah Dasar. Jurnal Edisi Khusus, 2(2), 79-85.

Sunila, N. M., Dantes, N., \& Candiasa, I. M. (2013). Pengaruh Model Pembelajaran Kooperatif Tipe Stad Kemampuan Numerik Siswa Kelas IV SD. E-Journal Program Pascasarjana Universitas Pendidikan Ganesha, 3.

Ukur, J. (2020). Manfaat Dan Kendala Administrasi Pendidikan Dalam Penyelenggaraan Pendidikan. Jurnal Ilmiah Research Sains Vol., 6(1).

Waluyohadi, A. E. G. W. (2018). Meta-analysis Study of Achievement Motivation and Academic Achievement. Journal PSIKODIMENSIA, 18(54), 101-108.

Wirnawati, Tampubolon, B., \& Asran, M. (n.d.). Pengaruh Media Konkret Pada Pembelajaran Matematika Terhadap Hasil Belajar Siswa SDN 15 Sempalai Tebas. Tanjungpura University.

Wuryanto, R. (2014). Keefektifan Model Pembelajaran LC 5E Dan TSTS Berbantuan LKPD Terhadap Hasil Belajar. Kreano: Jurnal Matematika Kreatif-Inovatif, $26-32$. https://doi.org/10.15294/kreano.v5i1.3274

Yurniwati, \& Handayani, R. (2019). Pengaruh Metode Realistic Mathematics Education terhadap Kemampuan Matematis Ditinjau dari Konsep Diri pada Siswa SD. Jurnal Nasional Pendidikan Matematika, 3(1), 27-39. 